\title{
It takes two to tango: the interplay between decision logics, communication strategies and social media engagement in start-ups
}

\author{
Christian Rudeloff ${ }^{1}$ (D) - Stefanie Pakura ${ }^{2}$ (D) Fabian Eggers $^{3}$ (D) \\ Thomas Niemand ${ }^{4}$ iD
}

Received: 26 November 2020 / Accepted: 10 April 2021 / Published online: 20 April 2021

(c) The Author(s) 2021

\begin{abstract}
This manuscript analyzes start-ups' usage of different communication strategies (information, response, involvement), their underlying decision logics (effectuation, causation, strategy absence) and respective social media success. A multitude of studies have been published on the decision logics of entrepreneurs as well as on different communication strategies. Decision logics and according strategies and actions are closely connected. Still, research on the interplay between the two areas is largely missing. This applies in particular to the effect of different decision logics and communication models on social media success. Through a combination of case studies with fuzzy-set Qualitative Comparative Analysis this exploratory study demonstrates that different combinations of causal and absence of strategy decision logics can be equally successful when it comes to social media engagement, whereas effectuation is detrimental for success. Furthermore, we find that two-waycommunication is essential to create engagement, while information strategy alone cannot lead to social media success. This study provides new insights into the role of decision logics and connects effectuation theory with the communication literature, a field that has been dominated by causal approaches.
\end{abstract}

Keywords Effectuation - Causation - Absence of strategy $\cdot$ Strategic communication $\cdot$ Communication management $\cdot$ Social media $\cdot$ Start-ups

Christian Rudeloff

c.rudeloff@macromedia.de

1 Media Faculty, Macromedia University of Applied Sciences, Hamburg, Germany

2 Management and Digital Markets, University of Hamburg, Hamburg, Germany

3 School of Business Administration, Menlo College, Atherton, USA

4 Department of Management and Economics, Clausthal University of Technology, Clausthal-Zellerfeld, Germany 


\section{Introduction}

Start-ups and small businesses typically face marketing challenges that can be related to a lack of resources, such as marketing skills, time, and money (Hills 1987). This also applies to the execution of social media communication strategies that, among other things, require a good understanding of the target customer, content writing and designing skills, a balancing of different social media channels and, in particular, sufficient time to execute (Eggers et al. 2017). As a result, social media communication activities run by start-ups and small firms often do not achieve the desired results, either because the firm does not use social media channels enough or tries to overachieve (Whitler 2019; Fischer and Reuber 2011).

This manuscript aims at finding ways to understand start-ups' social media communications and to increase the success of these activities. Although several studies exist that research strategic orientations as antecedents of social media success in small or young firms (e.g., Eggers et al. 2017; Fink et al. 2020), this paper adds a different perspective by arguing that the interplay of an entrepreneur's decision logic (effectual, causal, absence of strategy) and communication strategy (information, response, involvement) impacts the execution and ultimately the success of social media communication activities.

Since Sarasvathy's (2001) seminal paper on effectual decision logics, which focuses on currently controlled means and largely rejects planning for the future, a rich body of effectuation research emerged focusing on a variety of topics. Among others, studies analyze conceptual antecedents and consequences of effectuation and causation (e.g., Frese et al. 2020; da Costa and Brettel 2011; Ferreira et al. 2019; Johansson and McKelvie 2012) such as product/market strategy decisions (Deligianni et al. 2017), export/internationalization (Harms and Schiele 2012), R\&D project performance (Brettel et al. 2012) and new venture performance (Deligianni et al. 2017). Also, research focuses on overlaps and complementarity of effectuation with other concepts such as opportunity creation and bricolage (Fisher 2012; Welter et al. 2016).

Given the extensive work on effectuation, it is surprising that to date, only a few authors investigated the relationship between effectual decision logics and social media marketing. Fischer and Reuber (2011) analyze the impact of social media usage on entrepreneurs' decision logics. They find that effectual processes do not need to begin with an evaluation of means but may rather be started by social interaction itself. They show a feedback loop between the social media platform Twitter and effectual decision making processes. Further, they illustrate that very high levels of social media usage lead to effectual churn, which makes high levels of social media usage unproductive. In this regard, effectual churn is described as “(...) a continuous looping between social interaction through Twitter and the reassessment of means and effects available, without progression through the effectuation process" (Fischer and Reuber 2011, p. 20). How an entrepreneur's level of means is impacted by social media usage is also the focus of a study by Mumi et al. (2017). They propose conceptual arguments how 
an entrepreneur's attachment to social media influences her/his level of means. These means then impact effectual reasoning and in turn the entrepreneurial process including the recognition of market opportunities.

While the implementation of communication strategies (Grunig 2006; Morsing and Schultz 2006) has been intensively studied in the past decades (Ao and Huang 2020), there is a lack of research that focuses on the implementation of different social media communication strategies in entrepreneurial contexts. This is surprising, given how important communication is when it comes to building legitimacy for start-ups (Navis and Glynn 2011) and the prevalence of social media in communication management (Macnamara and Zerfass 2012). Studies demonstrate that social media communication is regarded as crucial by entrepreneurs (Bekmeier-Feuerhahn et al. 2016, 2018; Chen et al. 2017) and that entrepreneurial communication practices differ from those in larger corporations. But those studies do not come to consistent results regarding communication outcomes (Yue et al. 2019) such as engagement. Engagement as “customer's behavioural manifestations that have a brand or firm focus, beyond purchase, resulting from motivational drivers" (Van Doorn et al. 2010, p. 253) is crucial for brand experience in social media (Dolan et al. 2016) and may have a positive impact on firm performance (Kumar and Pansari 2016).

Against this background, this manuscript aims to address several research gaps. First, we want to find out how decision logics and communication strategies in social media are interconnected. Thereby, our paper attempts to extend the current state of research (Fischer and Reuber 2011; Mumi et al. 2017) in depicting not only the relationship between effectuation and social media, but more holistically the interplay between multiple decision logics and their corresponding communication strategies. Second, looking at effectuation, it has been shown that effectuation is the dominant decision logic among start-ups, given that it suits their characteristics best (Sarasvathy 2008). However, does this imply that effectual reasoning is always most successful (see also McKelvie et al. 2020)? In other words: Can a start-up that is inclined to use effectuation be more successful when using causal decision logics? The literature is largely silent in terms of the varying performance outcomes of decision logics. Along these lines, Hauser et al. (2020) propose to add strategy absence when comparing effectual and causal logics. Thus, we examine if effectual, causal or even an absence of strategic direction in combination with different communication strategies lead to social media engagement.

In summary, this manuscript explores the following research questions: How are entrepreneurial decision logics and social media communication strategies interconnected (RQ1) and do different combinations of decision logics and communication strategies lead to more or less social media engagement (RQ2)?

\section{Theory}

\subsection{Decision logics}

Effectuation is a decision logic that fits within the larger category of decisionmaking under uncertainty. Effectuation is based on the idea that entrepreneurs (and 
other decision makers) make decisions based on means that they currently control. Effectuators work with their own skills, knowledge, partners, financial capabilities, etc. and try to create business models that fit these means. Effectuators typically ask "Who am I?," "What do I know?" and "Who do I know?" and then create a business around the answers to these questions. By doing that, effectuators address market uncertainties by making their own future (Sarasvathy 2001). Effectual reasoning is supported by entrepreneurial expertise, which entrepreneurs acquire through successfully engaging in multiple ventures over time (Sarasvathy 2001; Read and Sarasvathy 2005). Recent research, however, shows that expertise is not imperative for effectual reasoning. Rather, entrepreneurial novices can apply this decision-making approach as well (Ruiz-Jiménez et al. 2020).

In contrast, a causal decision logic rests on the classical planning school and refers to the traditional view of entrepreneurship and business research where the decision-maker first sets a goal and then procures the necessary means to achieve it (e.g., Mintzberg 1978). The logic of strategic planning is that a company starts with an analysis of its environment and afterwards creates a plan which has clear achievement goals (Andersson 2011). Causal decision makers typically ask "If I want to reach this goal, what means do I need to possess or acquire to get there?".

Previous research has identified both decision logics in firms, in particular in smaller companies and start-ups (Reuber et al. 2016). It was shown that firms use both logics concurrently and switch between logics depending on growth stage, firm size and decision context (e.g., Read and Sarasvathy 2005; Berends et al. 2014; Nummela et al. 2014; Harms et al. 2021).

Looking at the effectuation concept, it is important to not only distinguish it from causation but to also define its unique characteristics. In fact, effectuation is not anything goes (or everything except causation) but a deliberate decision logic (Hauser et al. 2020). Along these lines, Hauser et al. (2020) propose a third construct: the absence of strategy. In their empirical study, they show differences between causal and effectual decision logics as well as absence of strategy approaches. Absence of strategy can be understood as a lack of consistency, either in decision-making or execution (Anwar and Hasnu 2016). Each decision might be optimal on a standalone basis but without alignment across decisions (Van den Steen 2016). Furthermore, a company lacks a strategy if it has not decided on organizational goals, scope, or competitive strategies (Hauser et al. 2020). Next to Hauser et al. (2020), several empirical studies have observed the existence of these non-strategies (e.g., Salavou 2010; Leitner and Güldenberg 2009; Rodwell and Shadur 2007).

Hauser et al. (2020) compare the three decision logics according to their underlying rationales. These rationales are mapped on five categories and are shown in Table 1.

\subsection{Communication strategies}

An important element of the decision logics is how they conceive relationships to outsiders. At the same time, different communication strategies describe distinct approaches in managing relationships with external stakeholders, which is based on 


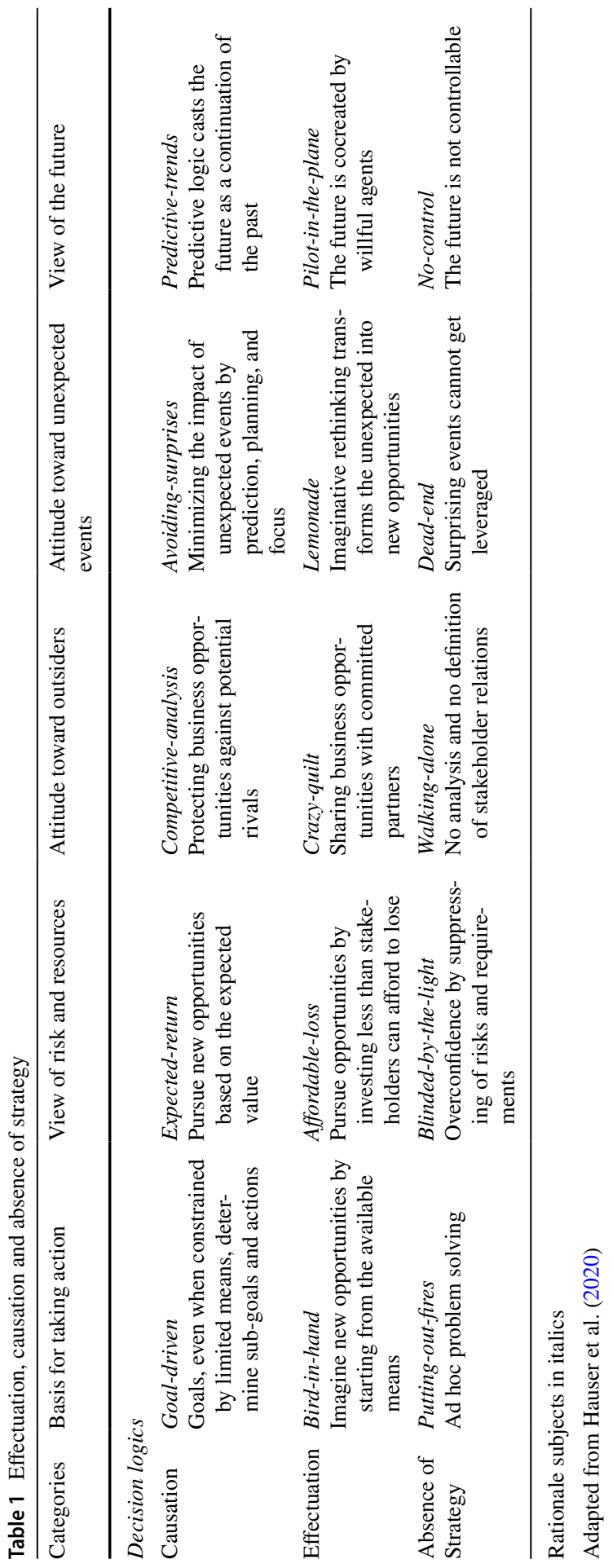


an explicit or implicit conceptualization of these groups. Therefore, we wonder if and how decision logics and communication strategies are interconnected in entrepreneurial practices. In other words: we wonder if and how the way how entrepreneurs make sense of stakeholder groups (which is grounded in their primary decision logics) is associated with their communication strategy in social media. We follow the definition of social media by Kaplan and Haenlein (2010) who define social media in general as the multitude of "internet-applications [...] that allow the creation and exchange of User Generated Content" but focus on social networking sites in particular. Pakura and Pakura (2015) for example showed that marketing capabilities in the context of social networking sites (such as Facebook) are directly linked to firm success.

Based on Morsing and Schultz' (2006) different stakeholder relationship strategies and according to the basic communication management models of Grunig and Hunt (1984) as well as its further discussion by Van Ruler (2004) three communication strategies can be distinguished: information, response and involvement.

Organizations can orient themselves towards informative communication, focusing on the dissemination of factual information through as many communication partners as possible. This approach can be characterized as "telling, not listening" (Grunig and Hunt 1984, p. 23) or as a one-way communication strategy, which relies on sense giving processes (Morsing and Schultz 2006). The stakeholder is seen as a passive entity who needs to be informed as objectively as possible. These start-ups will use social media networks primarily to post news-e.g., corporate, product or service developments, while stakeholder feedback is not intended.

Also, response communication tries to influence specific stakeholder groups in favor of the company. In contrast to the information strategy, response communication aims to engage stakeholders. Communication activities in this approach are often based on target group research and evaluation techniques. It is therefore a form of two-way communication. The objective of the response strategy is to initiate interactions in order to convince stakeholders of the attractiveness of the start-up and to generate public endorsements (Morsing and Schultz 2006). Typically, startups using a response strategy will implement social media networks to post promotional content that may include dialogue elements, e.g., raffles.

By contrast, an involvement communication strategy focuses on symmetric dialogue. The communication goal is to establish mutual beneficial and trusting relationships, therefore the stakeholder groups' interests are deliberately dealt with on an equal footing (Kent and Taylor 1998). Social networks are used to initiate and maintain dialogues so that stakeholders may participate in the start-up's development (Gao 2016; Rybalko and Seltzer 2010). Ideally, the start-up genuinely considers the stakeholders' feedback and adapts its corporate behavior accordingly (Kent and Taylor 1998). Therefore, while response and involvement are both two-way communications, response can be classified as two-way asymmetric, and involvement as two-way symmetric because of its dialogic character (Morsing and Schultz 2006; Grunig and Hunt 1984). Social media in general is seen as facilitating twoway symmetric communication (Macnamara and Zerfass 2012) and current research shows that two-way symmetric communication strategies may lead to user engagement in social media (Watkins 2017). Yet, so far there are only few studies which 
have analysed two-way communication strategies in start-ups. Table 2 presents an overview of the different communication strategies and their characteristics.

Regarding potential communication outcomes of different communication strategies, it could be expected that two two-way communication strategies are in general more successful than information communication (Grunig 2006). However, regarding the outcomes of communication strategies in a social media context, empirical studies come to unclear conclusions. While Kelleher (2009), Bortree and Seltzer (2009) and Del Mar Gálvez-Rodriguez et al. (2018) showed that interactive online communications correlate positively with several outcomes such as trust, satisfaction, commitment and participation, other studies do not support this finding (Rybalko and Seltzer 2010) or focus on public and non-profit organizations (Lai et al. 2020; Gao 2016; Linvill et al. 2012). As non-profit firms are likely to have an advantage in generating positive brand perceptions and endorsements in social media due to perceived brand warmth and higher symbolic values (Bernritter et al. 2016), these results may not be directly transferable to for-profit business settings. In an entrepreneurial context, Men et al. (2017) show how start-ups in China utilize involvement communication to create initial relationships with stakeholders. Regarding social media communications of entrepreneurs, existing studies confirm its relevance from the perspective of start-ups (Bekmeier-Feuerhahn et al. 2016) and demonstrate that entrepreneurial social media communication practices differ from those in larger corporations in relation to their messaging strategies (Yue et al. 2019). In analyzing Facebook activities of German start-ups, Pakura and Rudeloff (2020) come to the conclusion that understanding-oriented communication is correlated with social media success, however, Pakura et al. (2020) do not see an influence of communication strategies on follower engagement on Facebook but reveal networking practices and environmental scanning as success factors. All in all, the connection between different social media communication strategies and communication outcomes in start-ups remains unclear.

In addition, the interplay between decision logics and communication strategies and their effect on firm performance has not yet been investigated. As discussed above, Fischer and Reuber (2011) and Mumi et al. (2017) examine how entrepreneurs' social media usage correlates with their decision logics, however, they focus on effectuation and do not investigate the potential roles of causation and

Table 2 Communication strategies

\begin{tabular}{llll}
\hline & Information & Response & Involvement \\
\hline Objective & $\begin{array}{c}\text { Dissemination of infor- } \\
\text { mation }\end{array}$ & Persuasion & Mutual understanding \\
Nature of communication & One-way & Two-way asymmetric & Two-way symmetric \\
$\begin{array}{c}\text { Perception of stakehold- } \\
\text { ers }\end{array}$ & $\begin{array}{c}\text { Passive and unknown } \\
\text { entity }\end{array}$ & $\begin{array}{c}\text { Specified target groups, } \\
\text { based on research }\end{array}$ & Dialogue partners \\
$\begin{array}{c}\text { Activity in social media } \\
\text { networks }\end{array}$ & $\begin{array}{c}\text { Submitting factual news } \\
\text { Posting promotional } \\
\text { content }\end{array}$ & $\begin{array}{c}\text { Initiate dialogues, } \\
\text { generate feedback }\end{array}$ \\
\hline
\end{tabular}

On the basis of Morsing and Schultz (2006), van Ruler (2004), Grunig and Hunt (1984) 
strategy absence, neither do they consider social media outcomes. Our study aims to bridge this research gap. As it is a largely unexplored field, our research design is exploratory.

\section{Method}

\subsection{Sample}

In order to answer our research questions, we used qualitative methodologies and combined the case study approach with a fuzzy-set Qualitative Comparative Analysis (fsQCA). We further collected data from two different data sources to get a variety of insights (Olsen 2004). That is data from interviews with start-ups (1) and data from each start-up's social media network(s) (2).

Interview partners were identified through purposeful sampling. The sampling approach was aimed at including a high variation of different aspects so that the findings could reflect different perspectives or differences among young and entrepreneurial firms. To achieve high variation of a company's social media characteristics, one selection criteria was different social media usage, starting with zero channel activity. Therefore, our sampling method included typical cases and cases of varying intensity (Creswell 2013).

We further attempted to sample theoretically (Eisenhardt and Graebner 2007) for a potential range of uncertainty associated with start-ups in different development phases. According to Lambertz and Schulte (2013), the start-up process can last up to 6 years. Therefore, we selected some newer start-ups (less than 3 years old) and some more established firms (between 3 and 6 years old). We further verified that all sample companies were actively attempting to grow, which constitutes another important element of entrepreneurial ventures (Shane and Venkatraman 2000).

Through a mix of personal contacts, cold calls, and the snowball technique (one interviewee nominates others, e.g., Ashforth et al. 2007) we identified 10 start-up founders, who we interviewed between November 2017 and February 2018. Table 3 describes the interviewees and their related start-ups. It also includes a column on entrepreneurial expertise which indicates if the interviewees have previous experiences working with startups. All interviewees were either the founder, cofounder, or managing director of the firm. The interviews focused on questions relating to the key topics communication management, social media communication, business model, strategy, and company development.

With a total of 10 interviews our sampling fits well with Creswell's (2013) requirements for a heterogeneous group from 3 to 15 as a feasible sample size.

\subsection{Analysis}

To find proof for a start-up's decision logic we followed a phenomenological case study approach via semi-structured interviews (Gupta and Awasthy 2015; Creswell 2013). We conducted a preliminary study of two interviews to test and further 


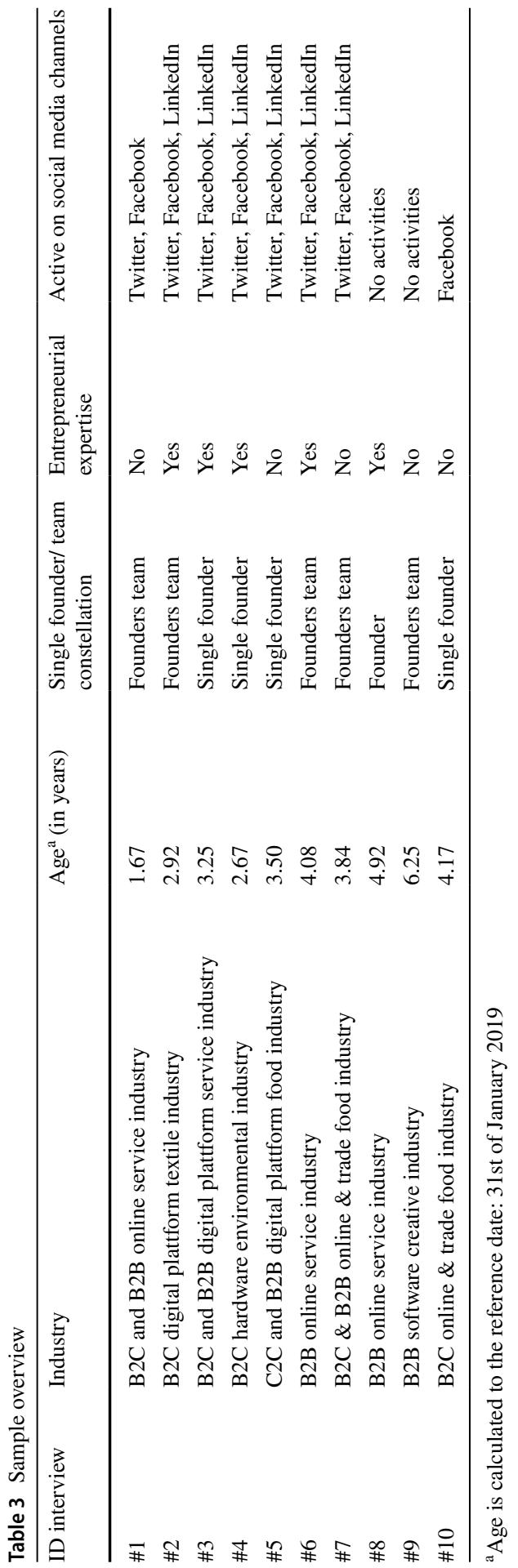


develop the semi-structured interview questionnaire. Specifically, in the main study we carried out in-depth interviews with the 10 start-up founders (McCracken 1988) to yield rich information and detailed answers from the individuals (Basu 2015; Miles and Huberman 1994). Interviews lasted on average around $45 \mathrm{~min}$. All interviews were audio-recorded and transcribed, which led to 180 pages of transcript.

We coded and further analyzed the interviews based on prior formulated, theoretically derived aspects of analysis. To that end, we developed a codebook (Appendix 1) from the theoretical background on the decision logics and their rationales (Mayring 2014). Here we checked with the interviews from the preliminary study and additionally read and re-read the collected interview data several times, thereby creating a coding schema based on Hauser et al. (2020) findings on decision logics (cf., Table 1). The final codebook consists of category definitions, prototypical text passages, and rules for distinguishing different decision logic categories in respect to the theoretical background. In all phases of the coding process, two trained researchers coded all interviews and reached inter-coder agreement (Miles et al. 2014). To ensure a high-quality coding process and to obtain the most appropriate solution, coding differences were determined, discussed and resolved. Thus, we met the requirement to provide an impression of the interviewee's subjective perception (Gioia et al. 2013). Additionally, we further analyzed the material based on Gioia et al. (2013) and used open coding. The open coding process was used to get further insights into the connection between the founders' decision logics and their social media communication strategies, closely reflected from the interviewee's expression. This approach enables us to answer our first research question: How entrepreneurial decision logics and social media communication strategies are interconnected.

To provide the reader with a better understanding of the data, we assembled data from the interviews to create Table 4, which shows the analysis on the founders' decision logics. Table 4 shows that most companies are dominated by an effectual logic, which is in line with previous research (Sarasvathy 2001; Tegtmeier and Meyer 2018). In fact, effectuation is the dominant decision logic in 8 out of 10 firms. In addition, we see that entrepreneurs use a mix of decision logics, which also corresponds with previous research (e.g., Read and Sarasvathy 2005; Nummela et al. 2014).

To find proof of a start-up's social media communication strategy (information, response, involvement), we collected data from each start-up's social media network(s). That is, we collected archival data by examining publicly available information about their social media activities on Facebook, Twitter, and LinkedIn. We collected any communication content that was posted by the 10 start-ups between January 1, 2018 and December 31, 2018 as well as all the related user comments, likes and shares.

Whereas engagement served as a measure for communication success, the posted social media content was analyzed through qualitative content analysis (Mayring 2014) to reveal communication strategies. Based on the theoretical background (cf., Table 2), we developed a codebook (Appendix 2) to differentiate between the three communication strategies in accordance with Morsing and Schultz (2006), van Ruler (2004) and Grunig and Hunt (1984). We applied systematic text analysis on each collected post $[\mathrm{n}($ all posts $)=1603]$ and coded in total $n=1278$ social media 


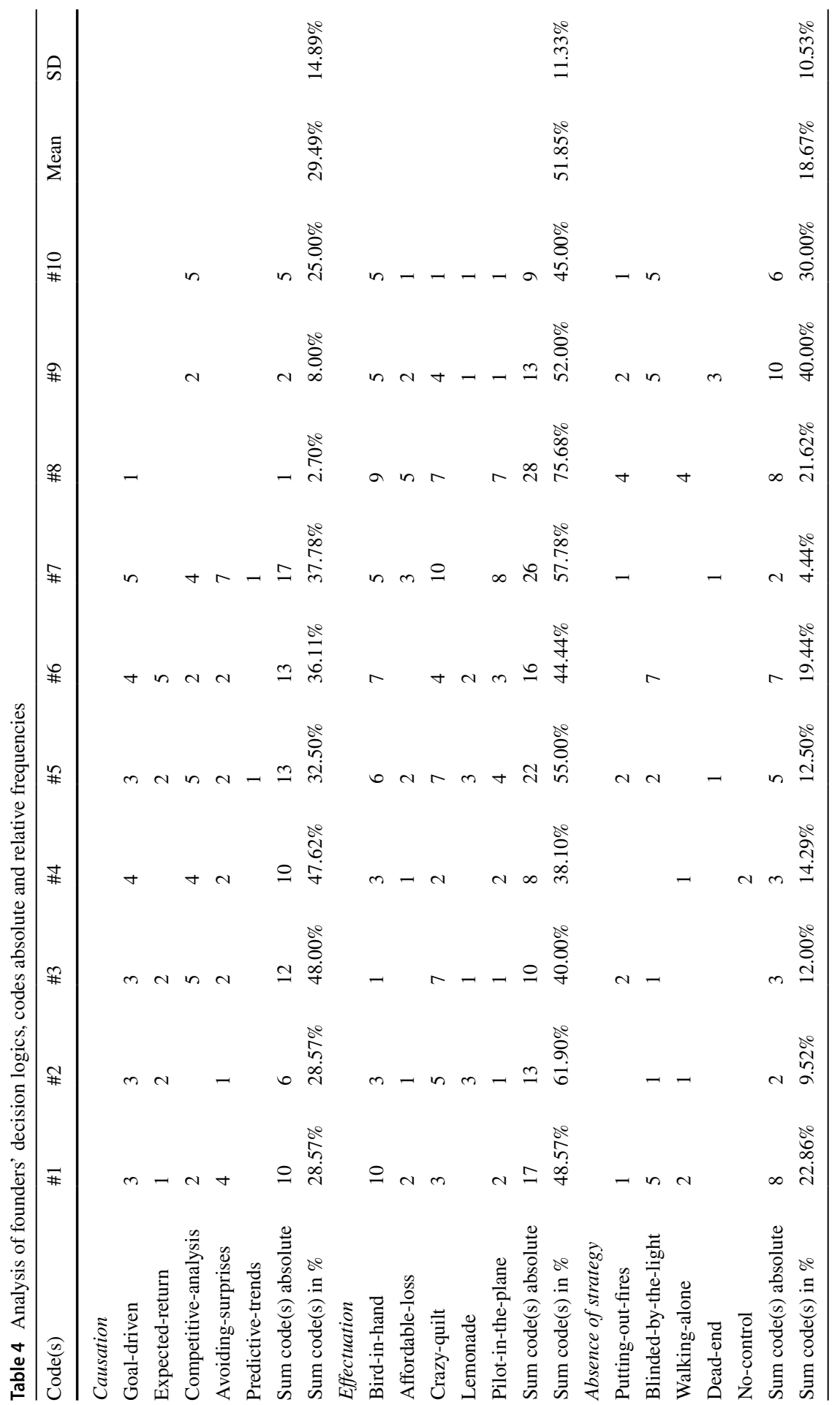


posts (which we refer to as: $\mathrm{n}$ (coded posts)). To achieve high inter-coder reliability (Miles et al. 2014) in all phases of the coding process, only trained members of the project team coded the posts. Furthermore, several feedback loops for text interpretation and coding rules were conducted and the researchers familiarized themselves with both the content and process of the creation of social media communication (Altheide 1996).

We used likes per posts and shares per posts as success measures. Likes per posts and shares per posts measure social media engagement. Table 5 presents the results on start-ups' social media communication strategies and performance. Table 6 shows the communication strategies and social media engagement across all interviews. Table 5 and Table 6 show that information and response strategies are most used among the start-ups in our sample. Both strategies are relatively evenly distributed, except for companies 2, 5, 7, which have a strong focus on response strategies. Two firms in our sample do not use their social media profiles at all (\#8, \#9).

In order to answer our second research question-whether different combinations of decision logics and communication strategies lead to more or less social media engagement-we used fuzzy-set Qualitative Comparative Analysis. Qualitative Comparative Analysis (QCA, Ragin 2008; Woodside 2013; Kraus et al. 2018) is a method that enables us to find combinations of decision logics and communication strategies that support social media success. In a nutshell, QCA uses joint configurations of independent variables (e.g. presence or absence of key drivers such as different decision logics and communication strategies) and determines whether a desired outcome (e.g. evidence of success such as social media likes, shares) has been consistently explained. QCA follows a case orientation, asking how many cases are present in a configuration, how consistently they explain the outcome (consistency) and how many of them are supportive compared to all cases (coverage). QCA also implements the principle of causal asymmetry. The presence of some configurations may explain social media success, while the opposite, the absence of those configurations explaining no success, is not assumed.

The following steps are necessary to conduct a QCA (Legewie 2013): (I) A truth table is built representing all possible configurations of the variables' manifestations (e.g., a level a1 of variable A exists simultaneously with a level b1 of a variable B), the respective frequency of cases where these configurations are present (e.g., 3 cases show levels of a1 and b1) and the consistency of the achieved outcome (e.g., 2 out of the present 3 cases yielded the outcome 1). (II) This truth table is reduced by removing rows with insufficient frequency and/or consistency. For example, a configuration might be deemed as unreliable when it is based on a single case (frequency $=1$ ) and has a consistency lower than 0.66 . This is done to avoid QCA giving weight to implausible configurations. (III) In this step, the truth table for a given outcome (e.g., 1) is minimized. That is, the configurations yielding the outcome are simplified until no further simplification can be achieved. For example, a path $\mathrm{a} 1 * \mathrm{~b} 1 * \mathrm{c} 1$ is reduced to $\mathrm{a} 1 * \mathrm{~b} 1$ if the presence of $\mathrm{c} 1$ is not relevant to the outcome while a1 and b1 are. The remaining configurations (prime implicants) are then understood as alternative paths to achieve the outcome.

Originally developed for small samples and as a mere qualitative technique to substantiate presumptions (Ragin 2008), QCA is frequently applied with large 


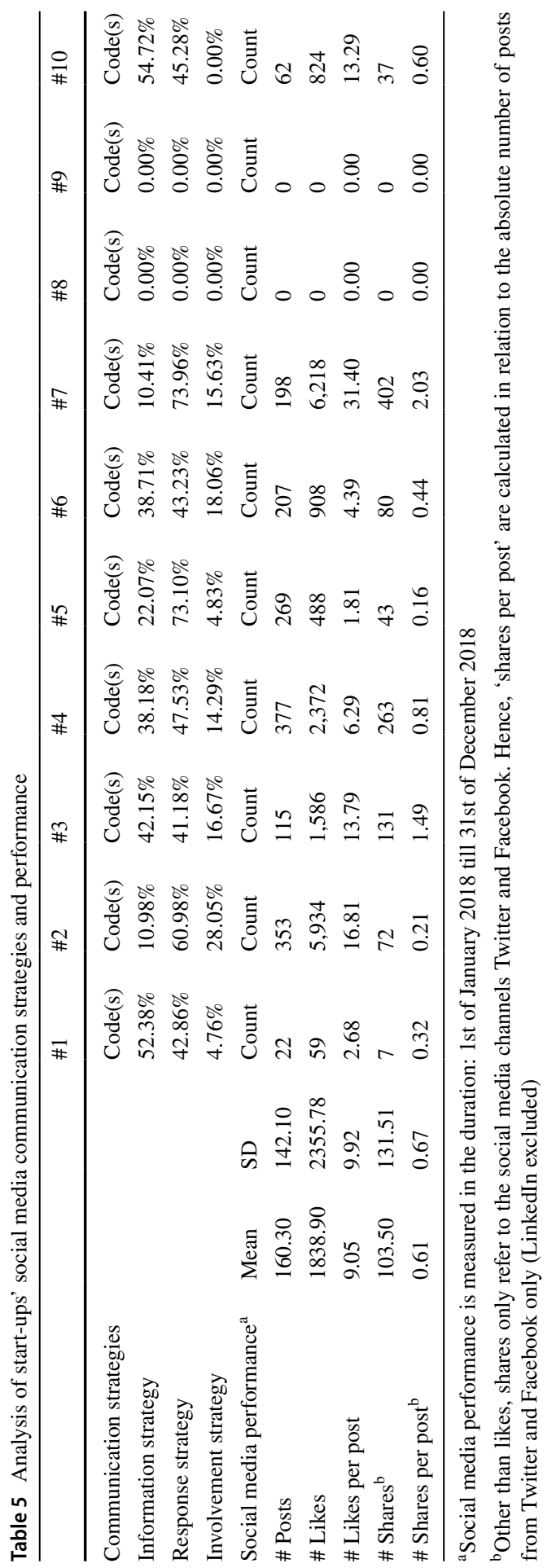


Table 6 Overall interviews: communication strategies and social media engagement

\begin{tabular}{llll}
\hline Communication strategies & \# Posts (in \%) & \# Likes per post & \# Shares per post \\
\hline Information strategy & $28.50 \%$ & 10.02 & 0.79 \\
Response strategy & $55.60 \%$ & 16.44 & 0.93 \\
Involvement strategy & $15.90 \%$ & 14.94 & 0.92 \\
\hline
\end{tabular}

${ }^{a}$ Frequencies for the count of posts of communication strategies are calculated over all interviews in total $-\mathrm{n}($ coded posts $)=1278$

This number differs from the collected posts over all interviews $-\mathrm{n}$ (all posts $)=1407$

samples, particularly using the fuzzy set-variant fsQCA (e.g., Eggers et al. 2020). Fuzzy sets allow the transformation of continuous variables into the absence-presence logic of QCA (range between 0 and 1). To clarify the present application and given the small sample in this research, we do not aim at representativeness and use clearly qualitative settings within the fsQCA framework (Schneider and Wagemann 2010). Hence, we selected a frequency cutoff of 1 together with an inclusion consistency threshold of 0.7 . Further, applying the $R$ package $Q C A$, all variables are calibrated using standard procedures, i.e., values are directly transformed to fuzzy sets via quantile thresholds $(0.05,0.23,0.41,0.59,0.77,0.95)$. All fuzzy sets show monotonously increasing relationships with their untransformed raw values as intended. Finally, minimization also relates to the standard settings as well (Consistency Cubes, cutoffs as described above). For the reasons discussed before, an absence of strategy is captured as the residual of effectuation and causation and logically omitted. It may be argued that communication strategies also show a residual perspective, i.e., that response communication is the communication style that is neither information nor involvement. In order to address this, we also present a second solution without response.

\section{Results}

\subsection{The interplay between decisions logics and communication strategy}

\subsubsection{Scenario 1}

Regarding RQ1, our results reveal three different scenarios regarding the interplay between decision logics and communication strategies. Three start-ups (\#2, \#5, \#7) showed a comparatively high level of effectuation and at the same time employed mainly response communication strategy in social media. For example, the founder of start-up \#5 describes the birth of his company as a process that started mainly from the means available to the entrepreneur, and not from prior market analysis or goal definitions. The company developed step by step: "It wasn't the case that we said 'Oh, there's a huge niche in the market, we have to go in there now and then we tinker a product around it', but it started small, it worked, it grew organically, it somehow made sense and then the project turned into a kind of part-time 
job and somehow a matter close to my heart and a bigger project, and the bigger project eventually became a company" (Interview, start-up \#5). Furthermore, the effectual logic of this case can be illuminated by its attitude toward competitors, as described by the founder: "So you meet again and again at events and exhibits or have email contact and help each other when it comes to the fact that you need help" (Interview, start-up \#5). This network- and dialogue-oriented relationship approach, which stands in contrast to the attempt to protect one's own business against rivalstypically seen in causal decision logic — was also claimed by the founder in regard to his start-up's social media communication. "This is very much dialogue oriented, because we always need feedback and (...) of course there is no point in simply sending a status update, (...)" (Interview, start-up \#5). Interestingly, the way the start-up actually executes its social media communication is-in contrast to the statements in the interview-overwhelmingly dominated by response communication. A typical post by start-up \#5 includes promotional content, such as advertisements for its products or raffles. Generating feedback and interaction is not in the foreground, as the following post by the start-up on Facebook exemplifies: "And we at (...) will show you how it's done. With our exclusive (...) voucher box you can taste our 25 absolute favorite locations. From cool street snacks to hip cafés to fine dining, everything is there. Until Saturday with the code Save 19\% for loved ones. (...)" (Facebook post, start-up \#5).

\subsubsection{Scenario 2}

We identified two start-ups (\#3, \#4) in our sample that-in contrast to the case described earlier - are characterized by a higher degree of causation decision logic. As an example of this type, start-up \#3 will be described in the following. While start-up \#5 evolved organically, the interview with the founder of start-up \#3 shows that founding his start-up was strongly goal-driven and largely based on analysis of the market situation: "For me, the main entry point to starting the business was the combination of the availability of technology right now for a very, very large group of people (...). The barriers to entry were very low. And that was combined with my personal drive for impact (...)" (Interview, start-up \#3). Furthermore, the attitude towards competitors is oriented mainly in the direction of rivalry and protection, as the following statement illustrates: "Compared to the competition, we tried to explain that we are the only player in Germany, which in turn is the largest market in Europe, which is why it is better to invest in us than in a European competitor" (Interview, start-up \#3). The founder of start-up \#3 even mentions legal confrontations with competitors. "We had another competitor who sued us directly, with whom I had less communication, but rather through the lawyers. And with competitors from other European cities, who are not taking my business away from me, but are taking away my investors" (Interview, start-up \#3). Furthermore, the business model of start-up \#3 is highly data-driven, which also represents a causal decision logic: the high priority of predictive logics and the attempt to minimize the impact of unexpected events. "If someone asked me what distinguishes us from the competition, I would say, it is first of all a technology-driven approach, that is, the goal is to use technology to map all processes that are extremely manual at almost all 
the competing companies" (Interview, start-up \#3). The goal-driven approach of this start-up is also mentioned by the founder in regards to the communication strategy: “(...) we started at some point and said what is everyone's goal, there is the (...) Objective Key Results Framework developed by Google, we introduced that and then said the objective for this quarter is (...)" (Interview, start-up \#3). In coding the social media communication of Case 3 we found a mix of information and involvement strategy. While some posts, especially on Twitter, communicated factual corporate news: "Big news today: we are thrilled to announce that we've raised $€ 15$ million in Series B (...). In 2019, we'll be investing in our product and expanding our business model across Germany" (Twitter post, start-up \#3), thereby representing the information strategy. Other posts revealed that the start-up uses social media to build a dialogue and even implements follower feedback: "You asked for it-our IT implemented it! Since the beginning of this week, you can specify your availability in our app. So you only get job offers that suit you in terms of time. Ready, Set, (...)" (Facebook post, start-up \#3).

\subsubsection{Scenario 3}

Finally, we identified five start-ups (\#1, \#6, \#8, \#9, \#10) which-in contrast to the aforementioned cases - showed relatively high degrees of strategy absence. In the following, start-up \#1 will be described. This company operates in B2B as well as B2C markets. As the interview with the founder of this start-up reveals, the development of the company as well as the social media communication of start-up \#1 can be partly characterized by absence of strategy elements. Concerning the company development, for instance, the founder mentions the ad-hoc-solving of "a few fundamental difficulties that were not really on the list of our founding partners either. We slipped into it a bit unsensitized and a week before the launch, a lawyer friend of mine looked at it again and gave us two or three elementary points to go along with" (Interview start-up \#1). The same pattern occurred in the interviews concerning the start-up's social media communication. The following statements demonstrate that the company didn't act strategically in regard to its messaging on social media: "We are going out now and just say 'attack,' it doesn't matter, just get out and whoever wants to imitate something has to do something first" (Interview, start-up \#1). Also, a target group definition seems to be lacking: "Externally, yes, I would say now let's talk to everyone" (Interview, start-up \#1). This start-up-in comparison to the aforementioned cases - only uses a minimal amount of involvement communication in its social media communications. Consequently, this company's social media posts were mostly about response and information strategy. A typical post on Twitter would offer factual information on the followers' legal rights: "You can also see a doctor during working hours-if there is no other way. Find out about your rights and exercise them! (...) \#working hours \# doctor visit \# termination" (Twitter post, start-up \#1). All in all, this company showed relatively low activity on social media. Accordingly, in the interview the founder stated the high relevance of face-to-face communication: "The more you depend on someone, the more important it is. So, I always try to make that happen as quickly as possible with a face-to-face conversation" (Interview, start-up \#1). 
Table 7 Solution for the outcome of likes per post (with response)

\begin{tabular}{|c|c|c|c|c|c|c|c|c|}
\hline & \multicolumn{2}{|c|}{ Decision logics } & \multicolumn{3}{|c|}{ Communication strategies } & \multicolumn{3}{|c|}{ Quality criteria } \\
\hline & Causation & Effectauation & Information & Response & Involvement & Cons & Cov & Uniq. Cov \\
\hline Path 1a & o & $\mathrm{o}$ & o & $\bullet$ & - & 0.867 & 0.480 & 0.305 \\
\hline Path 1b & $\bullet$ & $\mathrm{o}$ & $\bullet$ & O & $\bullet$ & 0.840 & 0.417 & 0.242 \\
\hline
\end{tabular}

Notes: Parsimonious solution. •: Presence, O: Absence, -: Not relevant

Cons.: Path consistency, Cov.: Path coverage, Uniq. cov.: Path unique coverage

Table 8 Solution for the outcome of shares per post (with response)

\begin{tabular}{|c|c|c|c|c|c|c|c|c|}
\hline & \multicolumn{2}{|c|}{ Decision logics } & \multicolumn{3}{|c|}{ Communication strategies } & \multicolumn{3}{|c|}{ Quality criteria } \\
\hline & Causation & Effectauation & Information & Response & Involvement & Cons & $\mathrm{Cov}$ & Uniq. Cov \\
\hline Path $2 \mathrm{a}$ & - & o & $\bullet$ & $\mathrm{O}$ & $\bullet$ & 0.927 & 0.517 & 0.322 \\
\hline Path $2 b$ & o & o & o & $\bullet$ & $\bullet$ & 0.816 & 0.363 & 0.168 \\
\hline
\end{tabular}

Parsimonious solution. •: Presence, ○: Absence, -: Not relevant

Cons.: Path consistency, Cov.: Path coverage, Uniq. cov.: Path unique coverage

\section{2 fsQCA on the interplay between decision logics, communication strategies and social media outcomes}

Addressing RQ2, and to gain a better understanding of the interplay between decision logics, communication strategies and social media engagement in terms of likes/post as well as shares/post, we conducted an fsQCA. First, we begin with an analysis that includes the response strategy (Tables 7, 8).

Our results reveal four paths of decision logics and communication strategies to shape social media success.

Regarding decision logics, our data shows that three different paths lead to social media success. The first type (path 1a) consists of firms with a low share of effectuation as well as causation. Both decision logics, effectuation and causation, are barely existent in these firms, therefore we call them "laissez-faire" start-ups. This type of start-up is also present in path $2 \mathrm{~b}$. Second, path $1 \mathrm{~b}$ identifies a type of start-up that uses a high proportion of causation and a low proportion of effectuation. We therefore call this type "planners." The third path (2a) consists of a low proportion of effectuation and a medium proportion of causation, as causation is "not relevant" for this path, indicating that causation is in the irrelevance range (close to 0.5) and therefore corresponding to a medium proportion. Compared to the "laissez-faire"start-ups, this indicates a lower share of strategy absence than for the given number of effectuation elements, so more causation is obvious. We call this third type the "real hybrids" as they show a limited amount of causation.

Regarding the relevant mix of communication strategies that lead to social media engagement, the fsQCA reveals start-ups that combine information and involvement communication. In other words, the posted content of these start-ups (path 1b: 
planners, path 2a: real hybrids) seems to be a mixture of informational pieces that can be received passively by the readers, and at the same time content that attempts to provoke feedback and discussions. We term this as an active-passive mix. In contrast, the second communication strategy combination consists of a high proportion of response communication with only a few elements of information strategy (path 1a). The content posted by these laissez-faire start-ups is aimed mainly at persuading followers in favor of the firm and its products or services. These promotional postings are combined with fewer content pieces that serve primarily to disseminate factual news and to provide information about, for instance, the company's current business activities. Hence, we call this the response-heavy mix. Third, another combination we found consisted also of a high proportion of response communication that comes with a high proportion of involvement (path 2b). Obviously, these laissez-faire start-ups combine promotional content with more interactive postings to initiate dialogues, hereafter called active-heavy mix.

To summarize, decision logics and communication strategies explain social media engagement. In regard to the engagement measure of likes per post, we could identify two success paths: First, start-ups with neither an emphasis on causation nor on effectuation (laissez-faire) can generate likes per post when they employ mainly a response communication strategy that is combined with few informational pieces (response-heavy). Second, start-ups which exhibit a higher degree of causation logic (planners) may successfully generate social media engagement with an active-passive mix of informational content (factual news) and posts that are more aimed at provoking discussions among their followers.

In regard to social media outcomes in terms of shares per post, we also revealed two paths to success. Start-ups that fall under the type of real hybrids can also generate engagement with a combination of information and involvement (active-passive) strategy (the same way planners may generate likes per post), while the fsQCA shows that laissez-faire start-ups must combine involvement and response to generate shares per post (active-heavy mix).

As proposed before, omitting response communication may be plausible. We thus reran the analysis without it and yielded comparable results regarding both decision logic types and communication mixes (Tables 9, 10). First, all three types, planners (path 3a resembles path 1a), laissez-faire startups (path $3 \mathrm{~b}$ resembles path 1a and $2 \mathrm{~b}$ ) and real hybrids (path 4 resembles path $2 \mathrm{a}$ ) are still present. Second, with response omitted (NA), planners (for likes per post, path 3a) and real hybrids (for

Table 9 Solution for the outcome of likes per post (without response)

\begin{tabular}{|c|c|c|c|c|c|c|c|c|}
\hline & \multicolumn{2}{|c|}{ Decision logics } & \multicolumn{3}{|c|}{ Communication strategies } & \multicolumn{3}{|c|}{ Quality criteria } \\
\hline & Causation & Effectauation & Information & Response & Involvement & Cons & Cov & Uniq. Cov \\
\hline Path 3a & $\bullet$ & o & $\bullet$ & NA & $\bullet$ & 0.827 & 0.441 & 0.242 \\
\hline Path $3 b$ & o & o & o & NA & • & 0.867 & 0.480 & 0.282 \\
\hline
\end{tabular}

Notes: Parsimonious solution. •: Presence, ○: Absence, -: Not relevant

Cons.: Path consistency, Cov.: Path coverage, Uniq. cov.: Path unique coverage 
Table 10 Solution for the outcome of shares per post (without response)

\begin{tabular}{|c|c|c|c|c|c|c|c|c|}
\hline & \multicolumn{2}{|c|}{ Decision logics } & \multicolumn{3}{|c|}{ Communication strategies } & \multicolumn{3}{|c|}{ Quality criteria } \\
\hline & Causation & Effectauation & Information & Response & Involvement & Cons & Cov & Uniq. Cov \\
\hline Path 4 & - & 0 & $\bullet$ & NA & $\bullet$ & 0.918 & 0.546 & NA \\
\hline
\end{tabular}

Parsimonious solution. •: Presence, O: Absence, -: Not relevant

Cons.: Path consistency, Cov.: Path coverage, Uniq. cov.: Path unique coverage

shares per post, path 4) can successfully generate engagement via an active-passive mix of informational and involvement communication, thereby resembling the previous results (paths $1 \mathrm{~b}$ and $2 \mathrm{a}$ ). Likewise, laissez-faire startups can turn to an activeheavy communication style when response is missing, as indicated before (path $3 \mathrm{~b}$ resembles path 2 b). Logically, as response is omitted, path 1a becomes irrelevant (Table 11).

Due to the small sample, QCA-specific information on solution and path quality should not be overstated. However, we found sufficient consistency (all paths $>0.8$ ), coverage (all paths $>0.3$ ) and unique coverage, i.e., incrementally contributing paths (all $>0.01$ ). Since path 4 is the only path of that solution, unique coverage is irrelevant. Solution quality is also sufficient with a coverage consistently larger than two thirds (for paths 1a and 1b: consistency $=0.856$, coverage $=0.723$; for paths $2 \mathrm{a}$ and $2 \mathrm{~b}$ : consistency $=0.848$, coverage $=0.685$; for paths $3 \mathrm{a}$ and $3 \mathrm{~b}$ : consistency $=0.856$, coverage $=0.723$ ).

\section{Discussion}

\subsection{Interpretation of results}

This study attempted to investigate the relationship between decision logics and communication strategies (RQ1) as well as social media engagement (RQ2) in

Table 11 Central results from QCA at a glance

\begin{tabular}{|c|c|c|c|c|c|}
\hline & \multirow{2}{*}{\multicolumn{2}{|c|}{$\frac{\text { Outcome }}{\text { Social media engagement }}$}} & \multicolumn{3}{|c|}{ Conditions (outcome achieved by...) } \\
\hline & & & Decision logic type & & Communication mix \\
\hline 1 & Likes per post & $:$ & $\begin{array}{l}\text { Laissez-faire (no strat- } \\
\text { egy) }\end{array}$ & + & Response-heavy \\
\hline 2 & Shares per post & : & $\begin{array}{l}\text { Laissez-faire (no strat- } \\
\text { egy) }\end{array}$ & + & $\begin{array}{l}\text { Active-heavy (response and } \\
\text { involvement) }\end{array}$ \\
\hline 3 & Likes per post & : & Planners (causation) & + & $\begin{array}{l}\text { Active-passive (information } \\
\text { and involvement) }\end{array}$ \\
\hline 4 & Shares per post & $:$ & $\begin{array}{l}\text { Real hybrids (moderate } \\
\text { causation) }\end{array}$ & + & $\begin{array}{l}\text { Active-passive(information } \\
\text { and involvement) }\end{array}$ \\
\hline
\end{tabular}


two ways: a qualitative case study approach and fsQCA. The qualitative case study revealed that high levels of effectuation coincide with response communication strategies. Causation relates to a mix of information and involvement strategies. Those companies that show a high degree of strategy absence (around or more than $20 \%$ of all codes) work with response and information strategies.

Concerning the success of different combinations of decision logics and communication strategies on the level of social media engagement, the fsQCA shows that effectuation does not play a role when running successful social media communication. In fact, in all paths, an absence of effectual decision logics is best when creating successful social media communication!

Interestingly, following neither causal nor effectual logics (absence of strategy) in combination with a response or response/involvement-oriented communication style leads to social media success. When causal decision styles are present, a combination of information and involvement communication styles is recommended. This is interesting since this combination was already found through the case study approach. fsQCA confirms that it leads to successful social media communication.

Regarding the role of communication strategies for creating social media engagement it can be stated that there is no single successful communication strategy. At the same time, as involvement communication strategies are part of most success paths, it is clear that two-way-communication is essential to create engagement. In other words: an information strategy alone cannot lead to social media success. This is not surprising as dialogue and feedback are crucial features of social media networks. Nonetheless, information strategy, while often associated with communication in mass media, still has its place in social media communication, as its presence in several paths suggests.

\subsection{Theoretical implications}

Our start-up interviews show that most follow an effectual decision logic. Interestingly, when looking at the fsQCA, effectual logics do not lead to communication success. On the contrary, effectuation seems to stand in the way of successful social media communications. This backs up the literature arguing that effectuation is the dominant decision logic in start-ups (see e.g., Sarasvathy 2008) and contradicts the literature that implicitly assumes that effectuation is beneficial in general and in a communications context in particular. As Fischer and Reuber (2010, p. 3) state, "social interaction is one key element in the effectuation perspective" hinting at a successful interplay of effectual decision logics with involvement communication.

Instead, the fsQCA reveals that a combination of strategy absence and response/ involvement communication leads to communication success, as most of the successful paths involve strategy absence. This is interesting since it is exactly the opposite of what the literature suggests. Absence of strategy may lead primarily to an information communication strategy, as this strategy is often practiced in an ad hoc-manner, requires less know-how and is less managed than the other two communication strategies (Hallahan et al. 2007). We see some support for this in the interviews, though the fsQCA comes to different conclusions. 
In both the interviews and the fsQCA, we find a combination of causal decision logics with information and involvement strategies. A causal decision logic is part of two success paths, which is in line with the mainstream view in strategic communication. This view is strongly associated with a causal decision logic as it emphasizes goal-driven communication programs (e.g., Austin and Pinkleton 2001), competitive analyses and brand positionings (e.g., Keller 2019) as well as expected returns and sophisticated communication evaluation techniques (Watson 2012). This approach is summarized in Holtzhausen and Zerfass' (2013) definition of strategic communication as the "practice of deliberate and purposive communication a communication agent enacts in the public sphere on behalf of a communicative entity to reach set goals" (p. 274).

At the same time, the QCA shows that deliberate decision logics, namely effectuation and, above all, causation are not necessary for creating social media engagement. That means that success is also possible without, for example, a fixed definition of stakeholders and can be based on ad-hoc problem-solving instead of long-term planning. This finding is especially interesting as it relates to the growing body of literature on emergent communication, in which the lack of predefined goals, a low level of formalization and an absence of purpose in many (successful) communicative practices is stated (Winkler and Etter 2018). In this context, Van Ruler (2015) argues that particularly in a digitalized communication environment, existing planning methods "provide an undesirable illusion of control" (p. 187) and are no longer suitable. Instead, she suggests that communication practices must be more flexible and open for change to be successful in the digital age. In fact, startups move further and further away from planning. This is not only evident in the increasing popularity of the business model canvas (Osterwalder and Pigneur 2013), which is set to replace the traditional business plan. Trial-and-error, pivoting and testing are also important cornerstones of start-up logics such as lean start-up (Ries 2011) and customer development (Blank and Dorf 2012) that are dominating the start-up world.

Our study provides initial empirical support for these theoretical reflections, as we see in our fsQCA that no-strategy decision logics can lead to social media engagement. The relevance of no-strategy logics is furthermore demonstrated in our case study analyses, which showed that all three decision logics occur simultaneously and are - to varying degrees-intertwined in communication activities of the start-ups we examined (see also Mansoori and Lackéus 2020).

\subsection{Practical implications}

We started this manuscript by pointing out Hills' (1987) statement that start-ups and small businesses face marketing challenges that can be related to a lack of resources, such as marketing skills, time, and money (Hills 1987). Social media communication is highly relevant for start-ups as it has the potential to generate engagement from stakeholders at relatively low costs. This is crucial as engagement in social media is not only linked to inducing word-of-mouth but may also lead to perceived 
trust (Islam and Rahman 2016) and therefore increased legitimacy (Welter and Smallbone 2006) and firm performance (Kumar and Pansari 2016).

However, the question is: How can start-ups start and engage in successful social media communication? This study showed that social media success depends on combinations of decision logics and communication strategies. In contrast to the literature, a surprising result is that effectual decision logics do not favor social media success. This is not to say that effectuation is bad for a start-up in general. However, our findings suggest that effectuation is not advised when engaging in social media. Here it is rather useful to follow a planned, causal approach, which for example is manifested in advice such as using a content calendar, studying other companies' social media posts and measuring social media success (Cooper and Tien 2020). Or, as an alternative, start-ups are advised to not follow any formal strategy when running social media campaigns. As described above, this manifests itself is advice such as trial-and-error, testing quickly and pivoting if necessary (Blank and Dorf 2012).

According to our QCA results, we see different combinations of communication strategies and chosen decision logics. Also, all three communication strategies lead to social media success, so our findings do not point to a specific, most successful strategy. At the same time, information strategy alone did not lead to engagement. Therefore, start-ups should avoid relying solely on one-way communication measures such as distributing facts and figures or simply uploading information material in social media networks that was created for other non-digital communication channels. In fact, a mix of posts - using content that alternates between information, response and involvement-is recommended. In the end, engaging followers with such a content mix not only makes sense from a theoretical but also from a practical point of view.

\subsection{Limitations and future research}

Our study has some limitations and offers directions for future research. First, the generalizability of our results might be limited due to our sample being exclusively from the German-speaking world. Nevertheless, our study shows empirical evidence for the interplay of decision logics, communication strategies, and communication success. Still, quantitative studies could explore how decision logics can further stimulate or mediate social media communication and social media communication success. We found evidence that an interplay between decision logics and communication strategies may impact social media success that calls for future research setting the empirical design up to a quantitative design. We suggest meditation models, such as a mediation by decision logics on communication strategies when studying social media success as an independent variable.

Second, we analyzed communication strategies and success and focused on the three key social media platforms (Twitter, Facebook, and LinkedIn). However, to avoid a selection bias, we double-checked for potential activities on other platforms to make sure that we did not overlook these activities. Even when companies were 
active in other networks (e.g., Instagram) we found that these activities were not much different from their activities in the networks under investigation.

Third, communication success is measured on social media only. Adding nonsocial media communication channels to measure communication success represents an interesting avenue for future research. Also, we only analyzed communication success and not overall business performance success.

Last, our case studies indicate that the implementation of communication strategies are not only associated with decision logics but also with the channel that is used to distribute the content. We find in the data that information strategy is typically implemented on Twitter, while involvement (and response) are rather used to communicate on Facebook. This finding is in line with the assumption that different social media channels not only come with different technical capabilities and features but also that they are associated with characteristic engagement experiences and expectations (Buzeta et al. 2020). Voorveld et al. (2018) found that Facebook is strongly associated with engagement expectations related to social interaction. Further studies should be implemented that take into account the role of different types of social media platforms in communication strategy building.

We hope that our study serves as a starting point to investigate the interplay of decision logics, communication strategies and communication success and ultimately supports the development of start-ups.

\section{Appendix 1: Codebook on decision logics}

\begin{tabular}{|c|c|c|c|c|}
\hline Category & Code(s) & Description & $\begin{array}{l}\text { Rule/ Coding } \\
\text { instruction }\end{array}$ & Example \\
\hline \multicolumn{5}{|l|}{ Causation } \\
\hline $\begin{array}{l}\text { Basis for taking } \\
\text { action }\end{array}$ & Goal-driven & $\begin{array}{l}\text { Goals, even when } \\
\text { constrained by } \\
\text { limited means, } \\
\text { determine sub- } \\
\text { goals and actions }\end{array}$ & $\begin{array}{l}\text { Interviewee names } \\
\text { concrete goals } \\
\text { (for the future) }\end{array}$ & $\begin{array}{l}\text { "And as you grow } \\
\text { your marketing } \\
\text { objectives change, } \\
\text { but in the early } \\
\text { days of a startup } \\
\text { and right now for } \\
\text { us it is more about } \\
\text { creating brand } \\
\text { awareness (...) } \\
\text { we have a market } \\
\text { strategy to accom- } \\
\text { plish that." }\end{array}$ \\
\hline $\begin{array}{l}\text { View of risk and } \\
\text { resources }\end{array}$ & Expected-return & $\begin{array}{l}\text { Pursue new oppor- } \\
\text { tunities based } \\
\text { on the expected } \\
\text { value }\end{array}$ & $\begin{array}{l}\text { Interviewee names } \\
\text { company (key) } \\
\text { figures }\end{array}$ & $\begin{array}{l}\text { "We try to work } \\
\text { more number } \\
\text { oriented. That is, } \\
\text { to see what works, } \\
\text { proof-of-concept } \\
\text { like, number } \\
\text { driven." }\end{array}$ \\
\hline
\end{tabular}




\begin{tabular}{|c|c|c|c|c|}
\hline Category & Code (s) & Description & $\begin{array}{l}\text { Rule/ Coding } \\
\text { instruction }\end{array}$ & Example \\
\hline $\begin{array}{l}\text { Attitude towards } \\
\text { outsiders }\end{array}$ & $\begin{array}{l}\text { Competitive- } \\
\text { analysis }\end{array}$ & $\begin{array}{l}\text { Protecting business } \\
\text { opportunities } \\
\text { against potential } \\
\text { rivals }\end{array}$ & $\begin{array}{l}\text { Interviewee sees } \\
\text { competition as } \\
\text { danger, fear that } \\
\text { business idea } \\
\text { will be "stolen", } \\
\text { distances own } \\
\text { business from } \\
\text { competitors }\end{array}$ & $\begin{array}{l}\text { "There is a pretty } \\
\text { large competitor } \\
\text { who received a } \\
\text { major financing } \\
\text { round and who is } \\
\text { of course a threat } \\
\text { for us, we have } \\
\text { them on the radar, } \\
\text { we are watching } \\
\text { them." }\end{array}$ \\
\hline $\begin{array}{l}\text { Attitude towards } \\
\text { unexpected } \\
\text { events }\end{array}$ & $\begin{array}{l}\text { Avoiding-sur- } \\
\text { prises }\end{array}$ & $\begin{array}{l}\text { Minimizing the } \\
\text { impact of unex- } \\
\text { pected events by } \\
\text { prediction, plan- } \\
\text { ning, and focus }\end{array}$ & $\begin{array}{l}\text { Interviewee talks } \\
\text { about analysis to } \\
\text { plan the future, } \\
\text { takes precau- } \\
\text { tions to achieve } \\
\text { desired results }\end{array}$ & $\begin{array}{l}\text { "(..) to give an } \\
\text { example, we } \\
\text { started Facebook } \\
\text { communication a } \\
\text { little later since we } \\
\text { first had to analyze } \\
\text { all these target } \\
\text { groups to start this } \\
\text { on the right foot" }\end{array}$ \\
\hline View of the future & Predictive-trends & $\begin{array}{l}\text { Predictive logic } \\
\text { casts the future } \\
\text { as a continuation } \\
\text { of the past }\end{array}$ & $\begin{array}{l}\text { Interviewee talks } \\
\text { about using key } \\
\text { business figures } \\
\text { from the past } \\
\text { to forecast the } \\
\text { future }\end{array}$ & $\begin{array}{l}\text { "(...) all these } \\
\text { numbers in the } \\
\text { background, } \\
\text { numbers that show } \\
\text { that we grow, } \\
\text { that the customer } \\
\text { base is stable and } \\
\text { grows, that the } \\
\text { software is stable, } \\
\text { that we have loyal } \\
\text { customers." }\end{array}$ \\
\hline \multicolumn{5}{|l|}{ Effectuation } \\
\hline $\begin{array}{l}\text { Basis for taking } \\
\text { action }\end{array}$ & Bird-in-hand & $\begin{array}{l}\text { Imagine new } \\
\text { opportunities by } \\
\text { starting from the } \\
\text { available means }\end{array}$ & $\begin{array}{l}\text { Interviewee refers } \\
\text { to previous } \\
\text { experiences, } \\
\text { jobs, acquaint- } \\
\text { ances, existing } \\
\text { (!) partnerships/ } \\
\text { networks }\end{array}$ & $\begin{array}{l}\text { "I built the partner- } \\
\text { ships through } \\
\text { active partnerships } \\
\text { of my past man- } \\
\text { agement consult- } \\
\text { ing projects." }\end{array}$ \\
\hline $\begin{array}{l}\text { View of risk and } \\
\text { resources }\end{array}$ & Affordable-loss & $\begin{array}{l}\text { Pursue opportuni- } \\
\text { ties by investing } \\
\text { less than } \\
\text { stakeholders can } \\
\text { afford to lose }\end{array}$ & $\begin{array}{l}\text { Interviewee uses } \\
\text { own financial } \\
\text { resources spar- } \\
\text { ingly. Inter- } \\
\text { viewee is aware } \\
\text { that only limited } \\
\text { funds are avail- } \\
\text { able }\end{array}$ & $\begin{array}{l}\text { "(...) from the start } \\
\text { we followed this } \\
\text { bootstrapping } \\
\text { approach, only } \\
\text { worked with own } \\
\text { resources." }\end{array}$ \\
\hline
\end{tabular}




\begin{tabular}{|c|c|c|c|c|}
\hline Category & Code(s) & Description & $\begin{array}{l}\text { Rule/ Coding } \\
\text { instruction }\end{array}$ & Example \\
\hline $\begin{array}{l}\text { Attitude towards } \\
\text { outsiders }\end{array}$ & Crazy-quilt & $\begin{array}{l}\text { Sharing business } \\
\text { opportunities } \\
\text { with committed } \\
\text { partners }\end{array}$ & $\begin{array}{l}\text { Interviewee talks } \\
\text { about build- } \\
\text { ing new (!) } \\
\text { partnerships with } \\
\text { competitors or } \\
\text { third parties }\end{array}$ & $\begin{array}{l}\text { "(...) this friend } \\
\text { is with us from } \\
\text { day one and } \\
\text { helps us out. He } \\
\text { worked on the } \\
\text { financial model, } \\
\text { on the legal form, } \\
\text { financial planning, } \\
\text { insurance, he } \\
\text { supported us with } \\
\text { a lot of things and } \\
\text { never asked once } \\
\text { to get anything in } \\
\text { return." }\end{array}$ \\
\hline $\begin{array}{l}\text { Attitude towards } \\
\text { unexpected } \\
\text { events }\end{array}$ & Lemonade & $\begin{array}{l}\text { Imaginative } \\
\text { rethinking } \\
\text { transforms the } \\
\text { unexpected into } \\
\text { new opportuni- } \\
\text { ties }\end{array}$ & $\begin{array}{l}\text { Interviewee refers } \\
\text { to situations } \\
\text { when he/she } \\
\text { learned from } \\
\text { mistakes, trial } \\
\text { and error prin- } \\
\text { cipal }\end{array}$ & $\begin{array}{l}\text { "(...) I believe } \\
\text { in the speed of } \\
\text { innovation, that } \\
\text { is making sure } \\
\text { that problems } \\
\text { and bottle necks } \\
\text { get solved asap } \\
\text { through learning } \\
\text { (...)." }\end{array}$ \\
\hline View of the future & Pilot-in-the-plane & $\begin{array}{l}\text { The future is } \\
\text { cocreated by } \\
\text { willful agents }\end{array}$ & $\begin{array}{l}\text { Interviewee } \\
\text { reports that prod- } \\
\text { ucts are devel- } \\
\text { oped together } \\
\text { with partners/ } \\
\text { customers. Inter- } \\
\text { viewee reports } \\
\text { that partners/ } \\
\text { customers pro- } \\
\text { vide feedback }\end{array}$ & $\begin{array}{l}\text { "The style has } \\
\text { always been very, } \\
\text { very personal, } \\
\text { very intense and } \\
\text { direct feedback } \\
\text { that is also our } \\
\text { company culture. } \\
\text { Through social } \\
\text { media we get } \\
\text { direct feedback, is } \\
\text { this cool or not so } \\
\text { cool." }\end{array}$ \\
\hline \multicolumn{5}{|l|}{ Absence of strategy } \\
\hline $\begin{array}{l}\text { Basis for taking } \\
\text { action }\end{array}$ & Putting-out-fires & $\begin{array}{l}\text { Ad hoc problem } \\
\text { solving }\end{array}$ & $\begin{array}{l}\text { Interviewee } \\
\text { talks about he/ } \\
\text { she responds } \\
\text { spontaneously } \\
\text { to acute critical } \\
\text { situations }\end{array}$ & $\begin{array}{l}\text { "But how do we } \\
\text { communicate to } \\
\text { the team and to } \\
\text { the customer that } \\
\text { has been ad hoc } \\
\text { and random." }\end{array}$ \\
\hline
\end{tabular}




\begin{tabular}{|c|c|c|c|c|}
\hline Category & Code(s) & Description & $\begin{array}{l}\text { Rule/ Coding } \\
\text { instruction }\end{array}$ & Example \\
\hline $\begin{array}{l}\text { View of risk and } \\
\text { resources }\end{array}$ & $\begin{array}{l}\text { Blinded-by-the- } \\
\text { light }\end{array}$ & $\begin{array}{l}\text { Overconfidence } \\
\text { by suppressing } \\
\text { of risks and } \\
\text { requirements }\end{array}$ & $\begin{array}{l}\text { Interviewee } \\
\text { reports his/her } \\
\text { hope/attitude } \\
\text { that "somehow" } \\
\text { something posi- } \\
\text { tives will occur }\end{array}$ & $\begin{array}{l}\text { "This one com- } \\
\text { petitor runs these } \\
\text { marketing and PR } \\
\text { things, we have } \\
\text { the strategy to } \\
\text { simply say we pig- } \\
\text { gyback a little bit } \\
\text { to raise awareness } \\
\text { for our company. } \\
\text { We believe the } \\
\text { competitor will } \\
\text { not survive for } \\
\text { long with this } \\
\text { approach, so their } \\
\text { PR, which they } \\
\text { started with their } \\
\text { financing, will } \\
\text { then be positive } \\
\text { for us." }\end{array}$ \\
\hline $\begin{array}{l}\text { Attitude towards } \\
\text { outsiders }\end{array}$ & Walking-alone & $\begin{array}{l}\text { No analysis and } \\
\text { no definition } \\
\text { of stakeholder } \\
\text { relations }\end{array}$ & $\begin{array}{l}\text { Interviewee does } \\
\text { not care about } \\
\text { contacts with } \\
\text { competitors. } \\
\text { No definition } \\
\text { of customers or } \\
\text { customer groups }\end{array}$ & $\begin{array}{l}\text { "We are creating } \\
\text { those things for } \\
\text { the first time so we } \\
\text { don't work with } \\
\text { any partners." }\end{array}$ \\
\hline $\begin{array}{l}\text { Attitude towards } \\
\text { unexpected } \\
\text { events }\end{array}$ & Dead-end & $\begin{array}{l}\text { Surprising events } \\
\text { cannot get lever- } \\
\text { aged }\end{array}$ & $\begin{array}{l}\text { Interviewee refers } \\
\text { to actions that } \\
\text { ended without } \\
\text { "profit" }\end{array}$ & $\begin{array}{l}\text { "Well yes, if we } \\
\text { couldn't solve it } \\
\text { we tried to solve } \\
\text { it at least through } \\
\text { communication. } \\
\text { We could solve } \\
\text { it but then the } \\
\text { one side was not } \\
\text { happy. That also } \\
\text { happens." }\end{array}$ \\
\hline
\end{tabular}




\begin{tabular}{|c|c|c|c|c|}
\hline Category & Code (s) & Description & $\begin{array}{l}\text { Rule/ Coding } \\
\text { instruction }\end{array}$ & Example \\
\hline View of the future & No-control & $\begin{array}{l}\text { The future is not } \\
\text { controllable }\end{array}$ & $\begin{array}{l}\text { Interviewee } \\
\text { believes that } \\
\text { present actions } \\
\text { have no bearing } \\
\text { on the future }\end{array}$ & $\begin{array}{l}\text { "You want in fact } \\
\text { provide a very } \\
\text { open environment } \\
\text { and culture to } \\
\text { your team so that } \\
\text { they collaborate } \\
\text { together and you } \\
\text { want them to } \\
\text { communicate. You } \\
\text { don't want any } \\
\text { control about it" }\end{array}$ \\
\hline
\end{tabular}

Adapted from Hauser et al. (2020)

\section{Appendix 2: Codebook communication strategies}

\begin{tabular}{|c|c|c|c|}
\hline Codes(s) & Description & $\begin{array}{l}\text { Typical activity in social } \\
\text { media / Coding instruc- } \\
\text { tion }\end{array}$ & Example \\
\hline Information strategy & $\begin{array}{l}\text { Unilateral dissemination } \\
\text { of information from the } \\
\text { start-up } \\
\text { One-way-communication } \\
\text { No stakeholder definition }\end{array}$ & $\begin{array}{l}\text { The start-up is submit- } \\
\text { ting factual news } \\
\text { No feedback is intended }\end{array}$ & $\begin{array}{l}\text { "cebit2018 here we come. } \\
\text { The crew is looking } \\
\text { forward to \#digital and } \\
\text { \#innovation. We are } \\
\text { excited for the new } \\
\text { format." } \\
\text { (translated from German) }\end{array}$ \\
\hline Response strategy & $\begin{array}{l}\text { The objective of the } \\
\text { communication is to } \\
\text { persuade stakeholders } \\
\text { Two-way-asymmetrical } \\
\text { communication } \\
\text { Specified target groups } \\
\text { based on research }\end{array}$ & $\begin{array}{l}\text { The start-up is posting } \\
\text { promotional content } \\
\text { that may include } \\
\text { dialogic elements, e.g. } \\
\text { raffles }\end{array}$ & $\begin{array}{l}\text { "Well, who is watching } \\
\text { 'Lions Den' tonight ,lion } \\
\text { emoji'? } \\
\text { Then get a lions deal: } \\
\text { our set of } 2 \text { exklusive } \\
\text { TASTES OF HAM- } \\
\text { BURG / BERLIN / } \\
\text { KÖLN voucher box with } \\
\text { 15\% discount ,present } \\
\text { emoji' } \\
\text { Just enter the code 'löwen- } \\
\text { dealhh' / 'löwendealber' } \\
\text { / 'löwendealcgn' in } \\
\text { your shopping cart ,lion } \\
\text { emoji'" } \\
\text { (translated from German) }\end{array}$ \\
\hline
\end{tabular}




\begin{tabular}{|c|c|c|c|}
\hline Codes(s) & Description & $\begin{array}{l}\text { Typical activity in social } \\
\text { media / Coding instruc- } \\
\text { tion }\end{array}$ & Example \\
\hline Involvement strategy & $\begin{array}{l}\text { The communication } \\
\text { objective is mutual } \\
\text { understanding } \\
\text { Two-way-symmetric } \\
\text { communication } \\
\text { Stakeholders are seen as } \\
\text { dialogue partners }\end{array}$ & $\begin{array}{l}\text { The start-up initiates } \\
\text { dialogues on eye level } \\
\text { The star-tup aims at } \\
\text { generating feedback } \\
\text { and signals to imple- } \\
\text { ment the feedback in } \\
\text { product, service or } \\
\text { corporate strategy }\end{array}$ & $\begin{array}{l}\text { "Inspired by \#Foodfor- } \\
\text { ThoughtBerlin, our food } \\
\text { \& beverage panel last } \\
\text { month, we've worked } \\
\text { with our wonderful } \\
\text { partners to assemble sus- } \\
\text { tainable recipes for you } \\
\text { to try at home: http://bit. } \\
\text { ly/2PEPxft } \\
\text { Let us know what you } \\
\text { think!" } \\
\text { (Original post is in } \\
\text { English) }\end{array}$ \\
\hline
\end{tabular}

On the basis of Morsing and Schultz (2006), van Ruler (2004), Grunig and Hunt (1984)

Funding Open Access funding enabled and organized by Projekt DEAL.

Open Access This article is licensed under a Creative Commons Attribution 4.0 International License, which permits use, sharing, adaptation, distribution and reproduction in any medium or format, as long as you give appropriate credit to the original author(s) and the source, provide a link to the Creative Commons licence, and indicate if changes were made. The images or other third party material in this article are included in the article's Creative Commons licence, unless indicated otherwise in a credit line to the material. If material is not included in the article's Creative Commons licence and your intended use is not permitted by statutory regulation or exceeds the permitted use, you will need to obtain permission directly from the copyright holder. To view a copy of this licence, visit http://creativecommons.org/licen ses/by/4.0/.

\section{References}

Altheide DL (1996) Qualitative media analysis. Qualitative research methods, vol 38. Sage, Thousand Oaks

Andersson S (2011) International entrepreneurship, born globals and the theory of effectuation. J Small Bus Enterp Dev 18(3):627-643. https://doi.org/10.1108/14626001111155745

Anwar J, Hasnu S (2016) Business strategy and firm performance: a multi-industry analysis. J Strateg Manag 9(3):361-382. https://doi.org/10.1108/JSMA-09-2015-0071

Ao SH, Huang QS (2020) A systematic review on the application of dialogue in public relations to information communication technology-based platforms: comparing English and Chinese contexts. Public Relat Rev 46(1):101814. https://doi.org/10.1016/j.pubrev.2019.101814

Ashforth B, Kreiner G, Clark M, Fugate M (2007) Normalizing dirty work: occupational tactics for countering occupational taint. Acad Manag J 50(1):149-174. https://doi.org/10.5465/amj.2007.24162092

Austin EW, Pinkleton B (2001) Strategic public relations management: planning and managing effective communication programs. Lawrence Erlbaum Associates, NJ

Basu TS (2015) Phenomenology: qualitative research - an Odyssey of discovery. In: Gupta RK, Awasthy $\mathrm{R}$ (eds) Qualitative research in management methods and experiences. SAGE Response, New Delhi, India, pp 71-80

Bekmeier-Feuerhahn S, Rudeloff C, Adam U (2016) Kommunikationsmanagement von Gründungen in der Kultur-und Kreativwirtschaft: Eine empirische Bestandsaufnahme. ZfKE-Zeitschrift für KMU und Entrepreneurship 64(1):21-45. https://doi.org/10.3790/zfke.64.1.21

Bekmeier-Feuerhahn S, Kollat J, Rudeloff C, Sikkenga J (2018) Intentionale vs. emergente Strategien der Online-Kommunikation von Gründungsunternehmen: Eine Status-quo-Betrachtung. In: Strategische 
Kommunikation im Spannungsfeld zwischen Intention und Emergenz. Springer, Wiesbaden, pp $195-213$

Bernritter SF, Verlegh PW, Smit EG (2016) Why nonprofits are easier to endorse on social media: the roles of warmth and brand symbolism. J Interact Mark 33:27-42. https://doi.org/10.1016/j.intmar. 2015.10.002

Berends H, Jelinek M, Reymen I, Stultiëns R (2014) Product innovation processes in small firms: combining entrepreneurial effectuation and managerial causation. J Prod Innov Manag 31(3):616-635. https://doi.org/10.1111/jpim.12117

Blank S, Dorf B (2012) The startup owner's manual. K\&S Ranch Press, Pescadero, CA

Bortree DS, Seltzer T (2009) Dialogic strategies and outcomes: an analysis of environmental advocacy groups' Facebook profiles. Public Relat Rev 35(3):317-319. https://doi.org/10.1016/j.pubrev.2009. 05.002

Brettel M, Mauer R, Engelen A, Küpper D (2012) Corporate effectuation: entrepreneurial action and its impact on R\&D project performance. J Bus Ventur 27(2):167-184. https://doi.org/10.1016/j.jbusv ent.2011.01.001

Buzeta C, De Pelsmacker P, Dens N (2020) Motivations to use different social media types and their impact on consumers' online brand-related activities (COBRAs). J Interact Mark 52:79-98. https:// doi.org/10.1016/j.intmar.2020.04.004

Chen ZF, Ji YG, Men LR (2017) Strategic use of social media for stakeholder engagement in startup companies in China. Int J Strateg Commun 11(3):244-267. https://doi.org/10.1080/1553118X.2017. 1298114

Cooper P, Tien S (2020) How to Create a Social Media Content Calendar: Tips and Templates. https:// blog.hootsuite.com/how-to-create-a-social-media-content-calendar. Accessed 13 November 2020

Creswell JW (2013) Qualitative inquiry and research design: choosing among five approaches. Sage, Thousand Oaks CA

da Costa AF, Brettel M (2011) Employee effectuation-what makes corporate employees act like entrepreneurs? Front Entrep Res 31(17):2

Deligianni I, Voudouris I, Lioukas S (2017) Do effectuation processes shape the relationship between product diversification and performance in new ventures? Entrep Theory Pract 41(3):349-377. https://doi.org/10.1111/etap.12210

Del Mar G-R, Sáez-Martín A, García-Tabuyo M, Caba-Pérez C (2018) Exploring dialogic strategies in social media for fostering citizens' interactions with Latin American local governments. Public Relat Rev 44(2):265-276. https://doi.org/10.1016/j.pubrev.2018.03.003

Dolan R, Conduit J, Fahy J, Goodman S (2016) Social media engagement behaviour: a uses and gratifications perspective. J Strateg Mark 24(3-4):261-277. https://doi.org/10.1080/0965254X.2015.10952 22

Eggers F, Hatak I, Kraus S, Niemand T (2017) Technologies that support marketing and market development in SMEs-evidence from social networks. J Small Bus Manage 55(2):270-302. https://doi.org/ $10.1111 /$ jsbm. 12313

Eggers F, Niemand T, Filser M, Kraus S, Berchtold J (2020) To network or not to network-Is that really the question? The impact of networking intensity and strategic orientations on innovation success. Technol Forecast Soc Chang 155:119448. https://doi.org/10.1016/j.techfore.2018.09.003

Eisenhardt KM, Graebner ME (2007) Theory Building From Cases: Opportunities And Challenges. Acad Manag J 50(1):25-32

Ferreira JJ, Fernandes CI, Kraus S (2019) Entrepreneurship research: mapping intellectual structures and research trends. RMS 13(1):181-205. https://doi.org/10.1007/s11846-017-0242-3

Fink M, Koller M, Gartner J, Floh A, Harms R (2020) Effective entrepreneurial marketing on Facebook—a longitudinal study. J Bus Res 113:149-157. https://doi.org/10.1016/j.jbusres.2018.10.005

Fisher G (2012) Effectuation, causation, and bricolage: a behavioral comparison of emerging theories in entrepreneurship research. Entrep Theory Pract 36(5):1019-1051. https://doi.org/10.1111/j.15406520.2012.00537.x

Fischer E, Reuber AR (2011) Social interaction via new social media:(How) can interactions on Twitter affect effectual thinking and behavior? J Bus Ventur 26(1):1-18. https://doi.org/10.1016/j.jbusvent. 2010.09.002

Frese T, Geiger I, Dost F (2020) An empirical investigation of determinants of effectual and causal decision logics in online and high-tech start-up firms. Small Bus Econ 54:641-664. https://doi.org/10. 1007/s11187-019-00147-8 
Gao F (2016) Social media as a communication strategy: content analysis of top nonprofit foundations' microblogs in China. Int J Strateg Commun 10:255-271. https://doi.org/10.1080/1553118X.2016. 1196693

Gioia DA, Corley KG, Hamilton AL (2013) Seeking qualitative rigor in inductive research. Organ Res Methods 16(1):15-31. https://doi.org/10.1177/1094428112452151

Grunig JE, Hunt TT (1984) Managing public relations. Harcourt Brace, Jovanovich College Publishers, Fort Worth, TX

Grunig JE (2006) Furnishing the edifice: ongoing research on public relations as a strategic management function. J Public Relat Res 18(2):151-176. https://doi.org/10.1207/s1532754xjprr1802_5

Gupta RK, Awasthy R (2015) Qualitative research in management methods and experiences. SAGE Response, New Delhi, India

Hallahan K, Holtzhausen D, Van Ruler B, Verčič D, Sriramesh K (2007) Defining strategic communication. Int J Strateg Commun 1(1):3-35. https://doi.org/10.1080/15531180701285244

Harms R, Alfert C, Cheng CF, Kraus S (2021) Effectuation and causation configurations for business model innovation: addressing COVID-19 in the gastronomy industry. Int J Hosp Manag. https://doi. org/10.1016/j.ijhm.2021.102896

Harms R, Schiele H (2012) Antecedents and consequences of effectuation and causation in the international new venture creation process. J Int Entrep 10(2):95-116. https://doi.org/10.1007/ s10843-012-0089-2

Hauser A, Eggers F, Güldenberg S (2020) Strategic decision-making in SMEs: effectuation, causation, and the absence of strategy. Small Bus Econ 54(3):775-790. https://doi.org/10.1007/ s11187-019-00152-X

Hills G (1987) Marketing and entrepreneurship research issues—scholarly justification? In: Hills G (ed) Research at the Marketing/Entrepreneurship Interface, vol 1. University of Illinois at Chicago, Chicago, pp 3-15

Holtzhausen DR, Zerfass A (2013) Strategic Communication-pillars and perspectives of an alternative paradigm. In: Zerfass et al (eds) Organisationskommunikation und public relations. Springer, Wiesbaden, pp 73-94

Islam JU, Rahman Z (2016) Linking customer engagement to trust and word-of-mouth on Facebook brand communities: an empirical study. J Internet Commer 15(1):40-58. https://doi.org/10.1080/ 15332861.2015.1124008

Johansson A, McKelvie A (2012) Unpacking the antecedents of effectuation and causation in a corporate context. Front Entrep Res 32(17):658-672

Kaplan M, Haenlein M (2010) Users of the world, unite! the challenges and opportunities of Social Media. Bus Horizons 53(1):59-68. https://doi.org/10.1016/j.bushor.2009.09.003

Kelleher T (2009) Conversational voice, communicated commitment, and public relations outcomes in interactive online communication. J Strat Commun 59(1):172-188. https://doi.org/10.1111/j.14602466.2008.01410.x

Keller KL (2019) Strategic brand management: building, measuring, and managing brand equity. Prentice Hall, Upper Saddle River, NJ

Kent ML, Taylor M (1998) Building dialogic relationships through the world wide web. Public Relat Rev 24(3):321-334

Kraus S, Ribeiro-Soriano D, Schüssler M (2018) Fuzzy-set qualitative comparative analysis (fsQCA) in entrepreneurship and innovation research-the rise of a method. Int Entrep Manag J 14(1):15-33. https://doi.org/10.1007/s11365-017-0461-8

Kumar V, Pansari A (2016) Competitive advantage through engagement. J Mark Res 53(4):497-514. https://doi.org/10.1509/jmr.15.0044

Lai CH, Ping R, Chen YC (2020) Examining government dialogic orientation in social media strategies, outcomes, and perceived effectiveness: a mixed-methods approach. Int J Strateg Commun 14(3):139-159. https://doi.org/10.1080/1553118X.2020.1749634

Lambertz S, Schulte R (2013) Consolidation period in new ventures: How long does it take to establish a start-up? Int J Entrep Ventur 4(5):369-390. https://doi.org/10.1504/IJEV.2013.058167

Legewie N (2013) An introduction to applied data analysis with qualitative comparative analysis. For Qual Soc Res 14(3):1-45

Leitner K, Güldenberg S (2009) Generic strategies and firm performance in SMEs: a longitudinal study of Austrian SMEs. Small Bus Econ 35(2):169-189. https://doi.org/10.1007/s11187-009-9239-x

Linvill DL, McGee SE, Hicks LK (2012) Colleges' and universities' use of Twitter: a content analysis. Public Relat Rev 38(4):636-638. https://doi.org/10.1016/j.pubrev.2012.05.010 
Macnamara J, Zerfass A (2012) Social media communication in organizations: the challenges of balancing openness, strategy, and management. Int J Strateg Commun 6(4):287-308. https://doi.org/10. 1080/1553118X.2012.711402

Mansoori Y, Lackéus M (2020) Comparing effectuation to discovery-driven planning, prescriptive entrepreneurship, business planning, lean startup, and design thinking. Small Bus Econ 54:791-818. https://doi.org/10.1007/s11187-019-00153-w

Mayring P (2014) Qualitative content analysis: theoretical foundation, basic procedures and software solution. https://nbn-resolving.org/urn:nbn:de:0168-ssoar-395173. Accessed 25 November 2019.

McCracken G (1988) The Long Interview. Sage, Thousand Oaks CA

McKelvie A, Chandler GN, DeTienne DR (2020) The measurement of effectuation: highlighting research tensions and opportunities for the future. Small Bus Econ 54:689-720. https://doi.org/10.1007/ s11187-019-00149-6

Men LR, Ji YG, Chen ZF (2017) Dialogues with entrepreneurs in China: how start-up companies cultivate relationships with strategic publics. J Public Relat Res 29(2-3):90-113. https://doi.org/10. 1080/1062726X.2017.1329736

Miles MB, Huberman AM (1994) Qualitative data analysis: an expanded sourcebook. Sage, Thousand Oaks, CA

Miles MB, Huberman AM, Saldana J (2014) Qualitative data analysis: a methods sourcebook. Sage, Los Angeles, CA

Mintzberg H (1978) Patterns in strategy formation. Manage Sci 24(9):934-948. https://doi.org/10.1287/ mnsc.24.9.934

Morsing M, Schultz M (2006) Corporate social responsibility communication: stakeholder information, response and involvement strategies. Bus Ethics Eur Rev 15(4):323-338. https://doi.org/10.1111/j. 1467-8608.2006.00460.x

Mumi A, Ciuchta M, Yang Y (2017) The influences of social media on entrepreneurial process: the theoretical understanding from effectuation theory. In: United States Association for Small Business and Entrepreneurship-Conference Proceedings, Boca Raton, pp 309-340

Navis C, Glynn MA (2011) Legitimate distinctiveness and the entrepreneurial identity: Influence on investor judgments of new venture plausibility. Acad Manag Rev 36(3):479-499. https://doi.org/10. 5465/amr.2008.0361

Nummela N, Saarenketo S, Jokela P, Loane S (2014) Strategic decision-making of a born global: a comparative study from three small open economies. Manag Int Rev 54(4):527-550. https://doi.org/10. 1007/s11575-014-0211-X

Olson WK (2004) Triangulation in social research: qualitative and quantitative methods can really be mixed. Developments in sociology. Causeway Press, Holborn, pp 103-121

Osterwalder A, Pigneur Y (2013) Business model generation: a handbook for visionaries, game changers, and challengers. Wiley

Pakura S, Pakura A (2015) Effects of Facebook activity on the performance of start-ups. An empirical study in the German craft business sector. Die Betriebswirtschaft 75(6):413-429

Pakura S, Rudeloff C, Bekmeier-Feuerhahn S, Eggers F (2020) Communication management of start-ups: an empirical analysis of entrepreneurs' communication and networking success on Facebook. Int J Entrep Ventur 12(5):459-489. https://doi.org/10.1504/ijev.2020.10032773

Pakura S, Rudeloff C (2020) How entrepreneurs build brands and reputation with social media PR: empirical insights from start-ups in Germany. J Small Bus Entrep. https://doi.org/10.1080/08276 331.2020 .1728490

Ragin C (2008) Redesigning social inquiry: Fuzzy sets and beyond. Chicago University Press, Chicago, IL

Read S, Sarasvathy SD (2005) Knowing what to do and doing what you know: effectuation as a form of entrepreneurial expertise. Journal of Private Equity 9:45-62. https://doi.org/10.3905/jpe.2005. 605370

Reuber AR, Fischer E, Coviello N (2016) Deepening the dialogue: new directions for the evolution of effectuation theory. Acad Manag Rev 41(3):536-540. https://doi.org/10.5465/amr.2015.0217

Ries E (2011) The lean startup: How today's entrepreneurs use continuous innovation to create radically successful businesses. Crown Business, New York, NY

Rodwell JJ, Shadur MA (2007) Strategy as a configuration of activities: evidence that strategy absence exists. Strateg Chang 16(1-2):43-55. https://doi.org/10.1002/jsc.786 
Ruiz-Jiménez JM, Ruiz-Arroyo M, del Mar F-F (2020) The impact of effectuation, causation, and resources on new venture performance: novice versus expert entrepreneurs. Small Bus Econ. https:// doi.org/10.1007/s11187-020-00371-7

Rybalko S, Seltzer T (2010) Dialogic communication in 140 characters or less: How Fortune 500 companies engage stakeholders using Twitter. Public Relat Rev 36(4):336-341. https://doi.org/10.1016/j. pubrev.2010.08.004

Salavou H (2010) Strategy types of service firms: evidence from Greece. Manag Decis 48(7):1033-1047. https://doi.org/10.1108/00251741011068752

Sarasvathy SD (2001) Causation and effectuation: toward a theoretical shift from economic inevitability to entrepreneurial contingency. Acad Manag Rev 26(1):243-263. https://doi.org/10.5465/amr.2001. 4378020

Sarasvathy SD (2008) Effectuation: elements of entrepreneurial expertise. Edward Elgar Publishing, Northampton, MA

Schneider CQ, Wagemann C (2010) Standards of good practice in qualitative comparative analysis (QCA) and fuzzy-sets. Comp Sociol 9(3):397-418. https://doi.org/10.1163/156913210X12493 538729793

Shane S, Venkatraman S (2000) The promise of entrepreneurship as a field of research. Acad Manag Rev 25(1):217-226. https://doi.org/10.2307/259271

Tegtmeier S, Meyer V (2018) Experts of thoroughness and fanatics of planning? Daring insights into decision-making of German entrepreneurs. Int J Entrep Small Bus 33(1):132-157. https://doi.org/ 10.1504/IJESB.2018.088685

Van den Steen E (2016) A formal theory of strategy. Manage Sci 63(8):2616-2636. https://doi.org/10. 1287/mnsc.2016.2468

Van Doorn J, Lemon KN, Mittal V, Nass S, Pick D, Pirner P, Verhoef PC (2010) Customer engagement behavior: theoretical foundations and research directions. J Serv Res 13(3):253-266. https://doi.org/ $10.1177 / 1094670510375599$

Van Ruler B (2015) Agile public relations planning: the reflective communication scrum. Public Relat Rev 41(2):187-194. https://doi.org/10.1016/j.pubrev.2014.11.008

Van Ruler B (2004) The communication grid: an introduction of a model of four communication strategies. Public Relat Rev 30(2):123-143. https://doi.org/10.1016/j.pubrev.2004.01.002

Voorveld HA, van Noort G, Muntinga DG, Bronner F (2018) Engagement with social media and social media advertising: the differentiating role of platform type. J Advert 47(1):38-54. https://doi.org/10. 1080/00913367.2017.1405754

Watkins BA (2017) Experimenting with dialogue on Twitter: An examination of the influence of the dialogic principles on engagement, interaction, and attitude. Public Relat Rev 43(1):163-171. https:// doi.org/10.1016/j.pubrev.2016.07.002

Watson T (2012) The evolution of public relations measurement and evaluation. Public Relat Rev 38(3):390-398. https://doi.org/10.1016/j.pubrev.2011.12.018

Welter F, Smallbone D (2006) Exploring the role of trust in entrepreneurial activity. Entrep Theory Pract 30(4):465-475. https://doi.org/10.1111/j.1540-6520.2006.00130.x

Welter C, Mauer R, Wuebker RJ (2016) Bridging behavioral models and theoretical concepts: effectuation and bricolage in the opportunity creation framework. Strateg Entrep J 10(1):5-20. https://doi. org/10.1002/sej.1215

Whitler KA (2019) The biggest marketing challenge for startups. https://www.forbes.com/sites/kimbe rlywhitler/2019/08/03/the-biggest-marketing-challenge-for-start-ups/\#4cc86a5c35c3 Accessed 25 November 2019.

Winkler P, Etter M (2018) Strategic communication and emergence: a dual narrative framework. Int J Strateg Commun 12(4):382-398. https://doi.org/10.1080/1553118X.2018.1452241

Woodside AG (2013) Moving beyond multiple regression analysis to algorithms: calling for adoption of a paradigm shift from symmetric to asymmetric thinking in data analysis and crafting theory. $\mathrm{J}$ Bus Res 66(4):463-472. https://doi.org/10.1016/j.jbusres.2012.12.021

Yue C, Thelen P, Robinson K, Men L (2019) How do CEOs communicate on Twitter? A comparative study between Fortune 200 companies and top startup companies. Corp Commun Int J 24(3):532552. https://doi.org/10.1108/CCIJ-03-2019-0031

Publisher's Note Springer Nature remains neutral with regard to jurisdictional claims in published maps and institutional affiliations. 